\title{
Tumors and biofilms: too much coincidences to be casual
}

\author{
S. V. Verevka, N. M. Voroshylova \\ State institution "O. S. Kolomiychenko Institute of Otolaryngology Of National Academy of Medical Sciences of Ukraine" \\ 3, Zoologichna, Kyiv, Ukraine, 02000 \\ verevka.biochem@gmail.com
}

The existence of the majority of microorganisms in the form of three-dimensional associates on the phase interface provides significant advantages as compared with unicellular planktonic ones. There is a strong similarity in properties of biofilms and malignant tumors that allows considering the latter ones as some kind of biofilms. Such point of view facilitates our understanding of some features of carcinogenesis and provides perspective directions in the prevention of metastases.

Ke y w o r d s: biofilms, carcinogenesis, metastasis

\section{The most widely distributed form of life}

Arthur Kornberg noted once, that multicellular organisms, including mammals, are the rare exclusion in the world that belongs to microorganisms [1]. Up to $95-99 \%$ of them exist in natural environments in the form of biofilms [2]. In other words, biofilms represent the most widely distributed and successful model of life on the Earth [2]. According to the universally acknowledged definition, they are aggregates of microorganisms in which cells are frequently embedded in a self-produced matrix of extracellular polymeric substances that are adherent to each other and/or surface [3]. All higher organisms, including humans, are colonized by microorganisms that form biofilms, which can be associated with persistent infections in plants and animals, and with contamination of medical devices and implants [5]. What are the advantages of associated form of microorganisms' life in contrary to quite rare free planktonic one? These advantages have to be extremely significant because they determine the choice of biofilm's form of life by immeasurable diversity of microorganisms. Unfortunately, the same advantages were suitable for multicellular organisms with the grave consequences for the latter.

\section{The importance of being biofilm}

Biofilms are complex systems that have high cell density, ranging from $10^{8}$ to $10^{11}$ cells $\mathrm{g}^{-1}$

C 2018 S. V. Verevka et al.; Published by the Institute of Molecular Biology and Genetics, NAS of Ukraine on behalf of Biopolymers and Cell. This is an Open Access article distributed under the terms of the Creative Commons Attribution License (http://creativecommons.org/licenses/by/4.0/), which permits unrestricted reuse, distribution, and reproduction in any medium, provided the original work is properly cited 
wet weight, and typically comprise many species. As a rule, biofilms are formed in flow system in the presence of the necessary growth substrates. A further source of heterogeneity is the ability of cells to undergo differentiation, which can be triggered by local conditions, and to coordinate life cycles that include stagespecific expression of genes and proteins. That is typical for the growth and development of microorganisms in spatially heterogeneous systems. The emergent properties of biofilm communities comprise novel structures, activities, patterns and properties that arise during their growth that leads to the formation of self-organized complex system [4]. There is an opinion that the key condition for the biofilms formation is the presence of some factor which suppresses significantly the growth of individual microorganisms [5]. This point of view has the right to exist, although often in the absence of adverse factors microorganisms are still inclined to form biofilms. The list of hostile factors seems to be endless and contains innumerous chemical toxicants, antibiotics, oxygen reactive species, metal ions, ionic force, temperature, $\mathrm{pH}$, detergents and desiccation. The list of has to be supplemented by more complicated defensive systems when we consider microorganisms living inside multicellular organisms. All these factors suppress the development of separate microorganisms and lead to the formation of biofilms. There are a lot of processes both at molecular and cellular levels that promote the intercellular association. Thus, the influence of an unfavorable factor alters the normal metabolism of microorganisms. This leads to the production of significant number of abnormal proteins, lipids, and carbohydrates that may be evalu- ated as some kind of endogenous intoxication at the simplest, unicellular level [6]. It is known that proteins with imbalanced or incomplete structures interact with outer cell membranes by quite rigid rules, which leads to the anchoring of hydrophobic residues inside membrane where as the positively charged ones were directed inside the cell ("positiveinside" rule [7]). Such allocation creates even ideal conditions for non-enzymatic glycosylation, or rather for interaction of intracellular part of the protein with numerous carbonylcontaining compounds, whose content in the cell increases sharply when cell is exposed to unfavorable factors. At the same time glycation of the protein intracellular part creates preconditions for exposure of bulky and chemically active carbohydrate derivatives on the cell surface. The following growth of extracellular cover may pass by well-known mechanisms of advanced glycation end products (AGEs) self-assembling with the formation of numerous intermolecular and intercellular bounds. In addition, non-functional glycation is a wellrecognized inducer of the conformational rearrangement of the protein molecules into $\beta$-fold structures that are capable of self-assembly into amyloid-like fibrils [8,9]. Formation of such mixed cover on the outer cell membrane protects to some extent the cell from the contact with hostile environment and persists at mitotic division to both newly formed cells. These and similar associative processes support the mutual adhesion of dividing cells and the formation of an extracellular polymeric substance (EPS). Evidently the given examples are far from the exhausting of the set of the processes that lead to the formation of threedimensional cells' coat, but even they are 
enough for the transformation into autochtonic parametabolic process that outruns cells division. At such look the community of freeborn microbes may be recognized as the miserable lump of the clayed poor fellows, that by the skin of their teeth survive in the hostile habitat. However, EPS isn't a simply amorphous gel that is composed by polysaccharides, lipopolysaccharides, and glycoproteins, but instead has a highly ordered three-dimensional structure that contributes to its function and emergent properties [10-12]. It provides the protection of microorganisms, redistribution of nutrients between individual cell layers and accumulation of active intracellular components in inaccessible for free microorganisms concentrations. EPS accumulates inside the matrix innumerous substances that may be inactivated or transformed into nutrients by various enzymes, that were secreted by cells and immobilized in EPS' net. All these properties transform the EPS matrix in some kind of external digestion system [13].

\section{Survivorship bias at microbial level}

There is no consensus on the causes of phenotypic variation of microorganisms at the biofilm forming. Some components of the extracellular polymeric substances may be mutagenic. The horizontal gene transfer may be also possible due to enriching the genome of compactly grouped microorganisms by various inclusions of extracellular DNA [4, 5]. The exchange on genetic information may play a notable role in the intercellular interactions in biofilm, but in clean and feed-abundant conditions such enrichments are at best useless and mutant forms lose to normal one, lag behind in the dynamics of reproduction and eventually disappear. Contrary, under the influence of an unfavorable factor, some (the rarest) change in the genome prove to be useful, ensuring to mutant form advantages in surviving and multiplication over an original form. It is impossible to exclude the possibility of evolutionarily formed permanent phenotype dispersion with an unchanged genotype. Phenotypic plasticity seems to be the most important prerequisite for survival. The community of the cells that are phenotypically different among themselves proves to be more adapted to survival and reproduction under the influence of any unfavorable factor. The plasticity of the phenotype is also necessary for the formation of internal layers of biofilm under conditions that differ from both an ideal pure medium and conditions of habitation of the outer layers of the forming film. Thus, at certain thickness of the outer layer the transition from aerobic metabolism to anaerobic one becomes in demand. No less useful are the abilities to supply catabolites of the outer layers' cells, extracellular polymeric substance, died or less aggressive cells, and even the material of the supporting surface $[4,14]$. Biofilms' habitat conditions predetermine an increase of aggressiveness and intensive production of lytic enzymes. The expansion of new food base supports the domination of the fittest iso-forms. Less successful cells as well as that ones which got under annoying conditions, are eliminated by more luckier relatives and bacteriophages [15]. In this way, spontaneously but regularly, feeding cavities, chanels, and pores are forming.

Deepening the cells' differentiation by the biofilm development leads to the formation of 
subpopulations with properties that are very different from the free form of the same cells. As a result, the concept has emerged of the special "biofilm phenotype", which in community is less sensitive for the influence of the corresponding unfavorable factors $[4,16]$. There is no doubt that the formation of "winning" lines is not a single act of creation, but proceeds permanently, with a constant rejection of less adapted forms. Therefore, the consideration of the formation of biofilms as a purposeful process is a typical example of a systematic survivorship bias - accounting for winning cases without considering the many losers. Of the many phenotypic forms that are formed, only those ones whose phenotype contributes to survival and reproduction under the yoke of an unfavorable factor or changed environmental conditions are observable. Both the initial planktonic form, and innumerous ones with useless or harmful changes of phenotype, lose in distribution and, as a result, lose in representation. But this doesn't mean that they are still not forming. From this point of view the systematically formed failure forms are an indispensable condition for the adaptation and survival of society as a whole. There is nothing unusual in this, if notify that microbes are the product of the selection during the myriad generations. The formation of the aggregate isn't a consequence of the sticking together of individual cells, but is the result of proliferation of the cellular forms which were more adapted to the given conditions. On these reasons biofilms are neither "fortresses" nor "cities", but they are the result of rigid selection of cells by phenotype conformity or inconsistency for the changed habitat conditions.

\section{Under the pressure of the immune system}

For obvious reasons, the features of biofilms' existence inside the higher organisms are of increased interest. The main feature of this coexistence is the presence of powerful protective systems designed to neutralize or remove the alien inclusions from the body. In this case, the recognition of «one's own» and «others» is determined by the presence or absence on the cells' surface of structural groups that don't conform to the structural rules adopted in this particular biological system [17]. One can confidently identify three key strategies for the survival of microorganisms under similar circumstances. The simplest and most successful one is based on the reaching of the maximal correspondence of the cell's surface to the structural rules adopted by multicellular proprietary organism. This strategy is the typical one for most obligate microorganisms that live in biofilms whose outer layer doesn't cause noticeable reaction of the host's defensive systems. A more complex case is represented by microorganisms that change antigenic determinants of the surface after the forming of a full-scale immune response to them. Such strategy is quite videspread among various bacterias and protosoas, which in contrast to Leopard may change their spots. For example, an African trypanosomias (Trypanosoma brucel) makes such transformations up to 20 times, that finally leads to the death of the host [18]. In such cases the decisive demands are the phenotypic plasticity and rigid selection of forms that were acceptable for changing environmental conditions. In some cases microorganisms may minimize the impact of immune 
system by formation of a kind of smoke barragen by intensive biosynthesis of the substances, which interaction with environmental components leads to the formation of immunogenic compounds with corresponding redistribution of the immune system's action. All the noted strategies do not contradict to each other and may be used together. So, Streptococcus pyogenes and Staphylococcus aureus are typical obligate microorganisms existing in the form of biofilms. They do not create any problems for the carrier at the normal functioning of the immune system. However, both of them produce intensively the proteins, that initiate activative processes resulting in the formation of significant amounts of immunogenic derivatives. Thus, streptokinase produced by Streptococcus pyogenes forms a complex with plasminogen circulating in the bloodstream. Such a complex, in turn, activates other molecules of plasminogen to free plasmin that is immediately blocked by $\alpha_{2}$-antiplasmin. The plasmin$\alpha_{2}$-antiplasmin complex is recognized by clearance systems as a protein to be eliminated immediately [19]. Staphylococcus aureus produces staphylokinase that acts similarly, even in some simplified manner. Both proteins possess little immunogenicity and are not needed for their cells-producers in itself, but derivatives of these proteins redistribute substantially the influence of immune system from producer cells. That leads to the survival of the latter in a state of quasi-stationary equilibrium with the host organism. Meanwhile, the weakening of immune system caused by any reasons reduces the restrictions of microorganisms' growth, that leads to the hard consequences.

\section{... let slip the dogs ...}

Mutual negative interactions of the familiar cells have also been observed in biofilms. Competition between cells inside biofilms can involve various killing mechanisms, such as those using antibiotics, bacteriocins, or extracellular membrane vesicles (which can contain enzymes that kill or impede the growth of competiting organisms), or strategies that compromise growth, such as nutrient depletion or the inhibition of quorum sensing [4, 20]. Thus, the binary biofilm is formed by two Ruminosoccus species, one of which forms a bacteriocin active against the other [21]. For the same reasons biofilms release significant amount of substances that inhibit the growth and reproduction of free planktonic forms as well as those ones which were pulled out by the biofilm on the late stage of maturation. These substances play the role of some kind of selfproduced adverse factor. That is why the possibilities of free cells' spreading with following forming new biofilms are determined by the complex of external unfavorable factors, by the ability of plankton forms for mutual binding, and by the availability of a substrate suitable for the primary sorption. No less significant is the ability of these microorganisms to retain certain phenotypic acquisitions irrespective of the initial conditions. That is why some phenotypes become even impossible to selfpropagation in the absence of hostile factor and are doomed to disappear. On the contrary, some other biofilm-origin microorganisms survive at returning to a free planktonic state, or rather, when dividing cells pass through this stage. That is the cause of the endless race between the spread of diseases which infectious agents became resistant to some antibio- 
tics and the development of qualitatively new drugs, for which the resistance has not been formed yet. In some cases the weakening of the master's organism counteraction leads to the spread of biofilm formed cellular iso-forms with increased aggressiveness and altered nutrient specificity. Therefore, the transformation of known obligate microorganisms at the weakening of the immune system into the hard damaging factor is natural and inevitable. Together with the previously developed resistance to antibiotics, this transformation can be lethal for the host.

\section{Too much coincidences to be casual}

The concept of biofilms has been proposed recently - in the mid-1980s [22]. It is widespread mainly among microbiologists, infectious disease specialists, biotechnologists and ecologists, whereas for the numerous representatives of other branches of biological and medical sciences it remains as a kind of exotics that is very far from their interests. However, even the simplest comparison of the regularities of formation and development of biofilms and malignant tumors is striking by similarity. In both cases we are dealing with the formation of three-dimensional associates of cells, which differ sharply from the environment. Whatever the reasons for the formation of malignant cells, a metabolic disorder is accompanied by a massive contamination of the outer cell membrane by the binding of the diverse extracellular material. This, on one hand, causes a regular reaction of the immune system, that may be considered as the powerful unfavorable factor that promotes the formation of the biofilm. On the other hand, high reactivity of the surface carbohydrate components provides both mutual recognition of tumor cells and endotheliocytes' surface, ensuring primary adhesion of tumor cells to the endothelium of the vessels of the target organ that is the key stage of metastasis [23, 24]. At the same time, the material adsorbed on the cell surface initiates a cascade of activative processes, that lead to the cleavage of surrounding tissues, the development of oxidative stress and other processes resulting in the formation of significant amounts of various abnormal metabolites [25]. Some of them, forming and accumulating in the tumor tissue in concentrations which are unattainable for a single cell, cause an unpredictable cascades of cells' transformations with a rigid selection of formed cellular isoforms according to the criteria considered above for the biofilms. Other components contribute to the tumor survival by damaging surrounding tissues and reducing the impact of the immune system by smoke screen of damaged proteins. The intercellular stroma of the tumor is a typical extracellular polymeric substance by both: its content and functions [26]. The presence of $\beta$-structured protein aggregates in stroma's composition is also understandable and is similar for the cases of biofilms and for some other tissues with disturbed metabolism [7]. It is worth to underline, that the formation of $\beta$-stacked protein aggregates in the living body in itself leads to severe consequences associated with the disruption of the normal functioning of a number of biological systems. A special group of tumor-producing substances are the tumors' restrictors, that more or less effectively block the interactions essential for metastasis and invasion $[27,28]$. Similarly to biofilms, the reaching of the three-dimensional tumor's size causes the cells' differentiation, 
formation of feeding vessels and changes in the character and intensity of the local metabolism. Thus, the increase in growth factors expression is the typical tumors feature and may be caused by phenotypic differentiation. At the same time the development of nonfunctional proteolysis, which is typical for malignant processes, leads to the activation of growth factors followed by intensification of angiogenesis, which is typical for tumor development, too [29]. All these alterations are not a directional process, but are the result of a complex of processes leading to the formation of phenotype-different forms with subsequent selection according to the criterion of the ability to survive and divide under permanently changing conditions.

The marked analogy of the processes of formation of biofilms and malignant neoplasms makes it possible to draw several conclusions that can have practical significance. If to examine tumor as a kind of a mature biofilm, the high phenotypic plasticity of the tumors' cellular society complicates significantly, if not excludes completely, the blocking of the malignant process by the body itself. The same reasons cause the formation of chemotherapyresistant forms similarly to the formation of antibiotic-resistant biofilms. Thus, the formation of cytostatics-resistant tumor cells is caused by a change in the lipid composition of their outer membranes, leading to decrease in permeability for cis-platin and doxorubicin $[30,31]$. At the same time, resistance to liposomal forms of these cytostatics has not been detected, which clearly indicates the advisability of using preparations with enhanced membrane permeability in the treatment of recurrent oncological diseases $[31,32]$. The process of metastasis is mediated by the stage of formation of a "floating island" of malignant cells [23]. By the analogy with the mechanisms of formation and development of biofilms, it it is possible to suppose that in this state the conglomerate of malignant cells is the most vulnerable. It is known that only a small part of malignant cells circulating in the bloodstream is capable of anchoring with the subsequent formation of a tumor. In other words, the limiting stage of the metastasis is the binding of floating cells to suitable landing sites on the intima of blood vessels. Similarly to the biofilm-forming processes, this process is limited by a number of tumor-produced substances that block the binding sites and bounded groups, which are responsible for cells' sorption. The elimination of tumor removes these blocking compounds, thus creating the prerequisites for relapse. This necessitates the postoperative use of angiostatins, trombospondins and similar substances for limitation of undesirable sorptive processes. An important consequence of the formation of antimetastatic-resistance is the increase in the aggressiveness of cells, which is associated with activity of the proteolytic enzymes. Thus, for cytostatics-resistant cells more than triple increase in trypsin-like activity was shown [33]. By analogy with the mechanisms of biofilm development, such increase in aggressiveness is a direct consequence of the selection of more aggressive cellular isoforms, which are more adapted for surviving under the pressure of more complicated complex of unfavorable factors. It is worth to emphasize that proteolytic enzymes formed due to non-functional activation are structurally damaged and can't be blocked by the protein inhibitors of blood 
circulation. This encourages the search for biocompatible inhibitors of proteinases, that are different in the mechanism of action from ineffective natural ones. For these reasons the experimental work on the suppression of recurrence by protein inhibitors of thrombin from the leech salivary glands deserve attention [34, 35]. It seems that such drugs may not only effectively prevent the development of postoperative thromboses, but also have significant antimetastatic effects.

\section{Conclusions}

The presented data testify for a possible similarity of the processes of the formation of biofilms and malignant tumors. It also follows that the formation of multicellular anomalies is largely mediated by the action of a complex of non-enzymatic processes. The components of this complex of reactions proceed autochthonically and independently, but their total action ensures the survival of more adapted cellular forms. Such an order is disastrous for less adapted cells, but it ensures the survival of society as a whole. In both cases, the formation and development of a multicellular associate is a consequence of a complex of biochemical and biophysical processes, that lead to the permanent formation of phenotypically different forms with permanent selection according to the changing environment, which is permanent, too. In the mature state both biofilms and tumors have increased resistance to a variety of unfavorable factors. Therefore, the suppression of undesirable processes is more effective at the early stages of their development that leads to the search for ways to influence on the less resistant early forms. Both biofilms and tumors produce substances that limit the spread of the free forms of corresponding cells. That is why the usage of these substances is necessary after tumor elimination. At the same time free cells' forms are more vulnerable for the substances, that are able to limit their aggressivity. The acquired resistance to one unfavorable factor is useless in relation to another one, that differs by mechanism of action. Accounting of these considerations seems to be worth of attention for the search of effective approaches for suppression of the malignant neoplasm development. One can not but agree with the opinion that in the study of the genesis of biofilms there are more questions than answers. The same can be said about the mechanisms of tumor formation and development. However, in both cases the expressed role of a complex of non-enzymatic reactions is traced, whose resulting effect leads to the formation of a stable multicellular associate.

\section{REFERENCES}

1. Kornberg A. Centenary of the birth of modern biochemistry. Trends Biochem Sci. 1997;22(8):282-3.

2. Stoodley P, Sauer K, Davies DG, Costerton JW. Biofilms as complex differentiated communities. Annu Rev Microbiol. 2002;56:187-209.

3. Vert M, Doi Y, Hellwich K-H, Hess M, Hodge P, Kubisa P, Rinaldo M, Schue F. Terminology for biorelated polymers and applications (IUPAC Recommendations 2012). Pure Appl Chem. 2012; 84(2):377-410.

4. Flemming HC, Wingender J, Szewzyk U, Steinberg P, Rice SA, Kjelleberg S. Biofilms: an emergent form of bacterial life. Nat Rev Microbiol. 2016;14(9):563-75.

5. Nikolaev YuA, Plakunov VK. Biofilm - "City of Microbes" or an analogue of multicellular organisms? Microbilolgy. 2007; 76(2):125-38.

6. Lozins 'ka LM, Semchyshyn HM. [Biological aspects of non-enzymatic glycosylation]. Ukr Biokhim Zh (1999). 2012;84(5):16-37. 
7. Verevka $S V$. Parametabolic $\beta$-aggregation of proteins: familiar mechanisms with diverse sequels. in: Ed Berhardt LV. Advances in Medicine and Biology. NY: Nova Science Publishers, 2013, 72: 29-48.

8. Vicente Miranda H, Outeiro TF. The sour side of neurodegenerative disorders: the effects of protein glycation. $J$ Pathol. 2010;221(1):13-25.

9. Volinsky $R$, Kinnunen PK. Oxidized phosphatidylcholines in membrane-level cellular signaling: from biophysics to physiology and molecular pathology. FEBS J. 2013;280(12):2806-16.

10. Hobley L, Harkins C, MacPhee CE, Stanley-Wall NR. Giving structure to the biofilm matrix: an overview of individual strategies and emerging common themes. FEMS Microbiol Rev. 2015;39(5):649-69.

11. Sutherland I. Biofilm exopolysaccharides: a strong and sticky framework. Microbiology. 2001;147(Pt 1):3-9.

12. Branda SS, Vik S, Friedman L, Kolter R. Biofilms: the matrix revisited. Trends Microbiol. 2005;13(1):20-6.

13. Tielen P, Kuhn H, Rosenau F, Jaeger KE, Flemming $H C$, Wingender $J$. Interaction between extracellular lipase LipA and the polysaccharide alginate of Pseudomonas aeruginosa. BMC Microbiol. 2013;13:159.

14. López D, Vlamakis H, Losick R, Kolter R. Cannibalism enhances biofilm development in Bacillus subtilis. Mol Microbiol. 2009;74(3):609-18.

15. Abedon ST. Bacteriophage exploitation of bacterial biofilms: phage preferencefor less mature targets? FEMS Microbiol Lett. 2016;363(3). pii: fnv246.

16. Cochran WL, McFeters GA, Stewart PS. Reduced susceptibility of thin Pseudomonas aeruginosa biofilms to hydrogen peroxide and monochloramine. $J$ Appl Microbiol. 2000;88(1):22-30.

17. Verevka $S V$. Formation and recognition of superficial microclusters as the integral part of processing of proteins. in: Eds. Boscoe AB, Listov CR, Protein Research Progress: New Research. NY: Nova Science Publishers, 2008:9-15.

18. Askers $J$. Normal immune responses to protosoal infections. In: Ed. Dick G. Immunological aspects of infectious diseases. Lancaster: MTP Press, 1979:77-115.

19. Kurkina T, Sambur M, Verevka S. Activating action of streptokinase and its rile in the injury of immune homeo-stasis. in: Ed. Zabolotny DI. Molecular Pathology of Proteins. N.Y.: Nova Science Publishers, 2009, 153-8.

20. Balsalobre C, Silván JM, Berglund S, Mizunoe Y, Uhlin BE, Wai SN. Release of the type I secreted alpha-haemolysin via outer membrane vesicles from Escherichia coli. Mol Microbiol. 2006;59(1):99-112.

21. Odenyo AA, Mackie RI, Stahl DA, White BA. The use of $16 \mathrm{~S}$ rRNA-targeted oligonucleotide probes to study competition between ruminal fibrolytic bacteria: development of probes for Ruminococcus species and evidence for bacteriocin production. Appl Environ Microbiol. 1994;60(10):3688-96.

22. Flemming HC. EPS-Then and Now. Microorganisms. 2016;4(4). pii: E41.

23. Chikina A, Alexandrova A. The cellular mechanisms and regulation of metastasis formation. Mol Biol. 2014; 48(2): 165-80.

24. Alizadeh AM, Shiri S, Farsinejad S. Metastasis review: from bench to bedside. Tumour Biol. 2014; 35(9):8483-523.

25. Verevka S, Grinenko T. Pseudo-functional interactions of plasminogen: molecular mechanisms and pathologic appearance. In: Ed. Berhardt LV. Advances in medicine and biology. NY: Nova Science Publishers, 2011; 34: 35-62.

26. Chekhun VF. Stroma - regulator of cancer cell progression. Onkologia. 2009; 11(3): 164-5.

27. Nyberg P, Xie L, Kalluri R. Endogenous inhibitors of angiogenesis. Cancer Res. 2005;65(10):3967-79.

28. Tykhomyrov AA, Vovchuk IL, Grinenko TV. Plasminogen and angiostatin levels in female benign breast lesions. Ukr Biochem J. 2015;87(5):103-12.

29. Kessenbrock K, Plaks V, Werb Z. Matrix metalloproteinases: regulators of the tumor microenvironment. Cell. 2010;141(1):52-67.

30. Yurchenko O, Todor I, Tryndyak V, Tregubova N, Kovtonyuk O, Solyanuk G, Kulik G, Chekhun V. Resistance of Guerin's carcinoma cell to cisplatin: biochemical and morphological aspects. Exp Oncol. 2003; 25(1):64-8.

31. Nosko MM, Pivnyuk VM, Solyanik GI, Kulik GI, Todor IN, Momot VY, Melnikov OR, Ponomareva $O V$, Chekhun VF. Biodistribution analysis of cisplatin in liposomal form in animals with cispla- 
tin-resistant and cisplatin-sensitive carcinoma. Exp Oncol. 2010;32(1):40-3.

32. Naleskina LA, Todor IN, Nosko MM, Lukianova NY, Pivnyuk VM, Chekhun VF. Alteration in lipid composition of plasma membranes of sensitive and resistant Guerin carcinoma cells due to the action of free and liposomal form of cisplatin. Exp Oncol. 2013;35(3):192-7.

33. Chekhun VF, Kovtonyuk OV, Todor IN, Kulik GI. Total proteolytic activity and levels of the main proteinase inhibitors in blood plasma of mice bearing Lewis lung carcinoma upon development of resistance to cisplatin. Exp Oncol. 2005;27(4):286-9.

34. Guo RR, Liu Y, Lu WL, Zhao JH, Wang XQ, Zhang $H$, Wang JC, Zhang $X$, Zhang $Q$. A recombinant peptide, hirudin, potentiates the inhibitory effects of stealthy liposomal vinblastine on the growth and metastasis of melanoma. Biol Pharm Bull. 2008;31(4):696-702.

35. Lu Q, Lv M, Xu E, Shao F, Feng Y, Yang J, Shi L. Recombinant hirudin suppresses the viability, adhesion, migration and invasion of Hep-2 human laryngeal cancer cells. Oncol Rep. 2015;33(3):1358-64.

\section{Пухлина та біоплівки: забагато співпадань, щоб бути випадковими}

\section{С. В. Верьовка, Н.М. Ворошилова}

Існування більшості мікроорганізмів у формі тривимірних асоціатів на межі розподілу фаз свідчить про іiї значні переваги такої для виживання, порівняно з дисперс- ною формою, та дозволяє визначити біоплівки як домінуючу форму життя. Спостерігається виражена подібність багатьох властивостей біоплівок та злоякісних пухлин, що дозволяє провести певну аналогію між ними. Подібний погляд полегшує розуміння окремих рис карциногенеза та створює передумови для обгрунтування перспективних напрямків попередження метастазування.

К л юч о в і с с о в а: біоплівки, карциногенез, метастазирование.

\section{Опухоль и биопленки: слишком много совпадений, чтобы быть случайными}

С. В. Веревка, Н. М. Ворошилова

Существование большинства микроорганизмов в форме трехмерных ассоциатов на границе раздела фаз свидетельствует о значительных преимушествах для выживания по сравнению с дисперсным существованием, что позволяет определить биопленки как доминирующую форму жизни. Наблюдается выраженное подобие множества свойств биопленок и злокачественных опухолей, что позволяет провести определенную аналогию между ними. Подобный взгляд облегчает понимание отдельных черт карциногенеза и создает предпосылки для обоснования перспективных направлений предупреждения метастазирования.

К л юч е в ы е с о в а: биопленки, карциногенез, метастазирование. 